Research Article

\title{
Green Care as Alternative Therapy: The Situation in Ghana
}

\author{
Evans Paul Kwame Ameade $\mathbb{D}^{1,2}$ Linda Ama Owusuaa Amoah, \\ and Benjamin Yeboah Ofori ${ }^{2}$ \\ ${ }^{1}$ Department of Pharmacy, School of Medicine and Health Sciences, University for Development Studies, Tamale, Ghana \\ ${ }^{2}$ Department of Animal Biology and Conservation Science, University of Ghana, Legon, Accra, Ghana
}

Correspondence should be addressed to Evans Paul Kwame Ameade; sokpesh@yahoo.com

Received 29 September 2020; Revised 20 March 2021; Accepted 27 March 2021; Published 7 April 2021

Academic Editor: Jose C Adsuar

Copyright (C) 2021 Evans Paul Kwame Ameade et al. This is an open access article distributed under the Creative Commons Attribution License, which permits unrestricted use, distribution, and reproduction in any medium, provided the original work is properly cited.

\begin{abstract}
Green care, an alternative healthcare system that involves the use of nature, is proven to be useful in the management of organic and psychological disorders worldwide. There are various forms of Green care including Animal-Assisted Therapy (AAT), a type where animals play pivotal roles in the healing process and is widely used in many developed countries. We assessed the level of awareness and attitude towards Green care among medical students of Ghana. Using a cross-sectional study design and a semistructured questionnaire designed on Google Forms, data were collected from randomly selected $4^{\text {th }}$-, $5^{\text {th }}$-, and $6^{\text {th }}$-year medical students of the University for Development Studies, Tamale, Ghana. The data submitted by 206 of the students were analyzed using Statistical Package for the Social Sciences, Version 25, and the results were presented as frequencies, percentages, and charts. The association between sociodemographic characteristics of respondents and awareness about Animal-Assisted Therapy (AAT) was considered significant at $p<0.05$. The study found that only $7(3.4 \%)$ of the medical students had ever heard of Green care while a higher number of $36(17.5 \%)$ were aware of AAT mostly through movies and television. However, the majority, $122(59.3 \%)$, had a positive attitude towards the introduction of AAT, into their medical training curriculum. Up to 146 (70.9\%) of the respondents suggested lectures and practical sessions as their preferred way of acquiring knowledge and skills on AAT. Only the sex of the respondents was significantly associated with awareness of AAT, with females having a better awareness of AAT $(28.6 \%$ vs. $11.0 \%, p=0.003)$. We conclude that awareness of Green care practices among medical students in Ghana was highly inadequate, but the desire of the majority of them to acquire knowledge and skills in this proven alternative therapy makes its future use in Ghana promising.
\end{abstract}

\section{Introduction}

The use of nature for the promotion of human health, which is collectively known as Green care, is becoming a promising alternative healthcare practice, especially in developed countries [1, 2]. Green care is defined as an alternative therapy that uses the biotic (living) and abiotic (nonliving) components of nature to promote human health and wellbeing $[1,3]$. Although Green care may be linked to the natural environment, it can also occur in designated facilities such as hospitals, nursing homes, and prisons [4, 5]. Green care intervention processes can be classified into social and therapeutic horticulture, care farming, ecotherapy, and animal-assisted therapy among others [1]. Social and therapeutic horticulture involves the use of plants and horticulture to promote human wellbeing [6]. Care farming processes, on the other hand, encompass the use of commercial farms and agricultural landscape to promote mental and physical health, while ecotherapies are techniques and practices which encourage clients to work with plants and animals and are supported to establish a green space to conserve local habitats [7-10]. Animal-assisted therapy involves the use of trained animals such as dogs, cats, horses, and donkeys to promote mental and physical health $[1,11,12]$.

Animal-assisted therapy (AAT) is the most thoroughly studied Green care method [1, 4]. Physiological benefits derived from Green care have been proven to be effective as 
its application had reportedly led to a significant reduction in abnormal heart rates, blood pressure, and pain [13-15]. Examples of documented psychiatric or neurological disorders that have been cured or managed using Green care or AAT include schizophrenia, personality disorders, depressions, acute stress reactions, multiple sclerosis, dementia, and bipolar affective disorders, as well as drug addictions $[1,2,16-22]$. Historical records show that Green care was practiced in hospitals, prisons, monasteries, and churches in the Middle Ages, but the practice of this alternative therapy has recently gained enormous patronage in many developed countries including the United Kingdom, United States of America, Sweden, Norway, Germany, Spain, Australia, Netherlands, and Belgium among others [3, 12, 18, 23, 24].

Developing countries, especially those in the tropics, including sub-Saharan Africa, have the greatest diversity of fauna and flora, which are important components of Green care practices $[25,26]$. However, there seems to be a paucity of studies on the use of this alternative therapy in human health promotion in the developing world including Africa. Medical doctors and other health practitioners are key persons who could promote Green care therapy if they are abreast with the use and importance of Green care as an alternative therapy for some chronic diseases. The present study, therefore, evaluated the awareness level and attitude toward Green care therapy among medical students in Ghana. The result of this study could cause health educators and policymakers to take the appropriate actions on how these would-be physicians and other health practitioners can make this alternative therapy available and beneficial to the Ghanaian populace.

\section{Methods}

2.1. Study Design, Setting, and Population. Data were collected from clinical-level medical students of the University for Development Studies, Tamale, Ghana, in a quantitative research using a cross-sectional study design. The study was conducted between July and August 2020. The University for Development Studies (UDS) was established as the first university in Northern Ghana in 1992. It is located in the Tamale metropolis, the only northerly located city in Ghana, and is geographically situated between latitude $9^{\circ} 16$ and $9^{\circ}$ 34 North and longitude $0^{\circ} 36$ and $0^{\circ} 57$ West [27]. During the last national population census in 2010, Tamale was reported to have a population of 233,252 [27]. The respondents were clinical-level medical students of the School of Medicine and Health Sciences of the UDS undertaking their junior and senior clerkships at the Tamale Teaching Hospital, the only tertiary-level medical facility in Northern Ghana.

2.2. Sample Size. The Cochran formula, $n_{0}=t^{2}(p)(q) / d^{2}$ [28], was used to calculate the sample size for this study, where $t=1.96$, the value for a selected alpha level of 0.025 in each tail; $d=0.05$ considered as an acceptable margin of error for proportion; and $p$ is the estimated proportion of an attribute that is present in the population, which is considered as 0.5 or $50 \%$ since there is a paucity of data on the level of awareness on Green care in Ghana; hence, $q=0.5$ $(q=1-\mathrm{p})$.

$$
\begin{aligned}
& n_{0}=\frac{1.96^{2}(0.5)(0.5)}{0.05^{2}}, \\
& n_{0}=384 .
\end{aligned}
$$

Since 384 exceeds the $5 \%(487 \times 0.05=24.4)$ of the eligible study population of 487 and excluding the 28 students who took part in the piloting of the study tool, an adjusted sample size $n_{1}$ was calculated using the Cochran correction formula:

$$
\begin{aligned}
& n_{1}=\frac{n_{0}}{1+n_{0} / \text { Study population }} \\
& n_{1}=\frac{384}{1+384 / 459} \\
& n_{1}=209
\end{aligned}
$$

with a total response of 206 obtained at the end of the data collection, and this study had a response rate of $98.6 \%$ (206/ $209 * 100)$.

2.3. Sampling Procedure. Simple random and proportionate sampling techniques were applied in this study. The lists of all the students in the $4^{\text {th }}-(215), 5^{\text {th }}-(137)$, and $6^{\text {th }}-(135)$ year classes were obtained together with their WhatsApp numbers from their class leaders who sought their consent on behalf of the researchers. Using the Microsoft Rand function, the arrangement of the class lists was randomized. Using proportionate sampling, the numbers required for the piloting of the questionnaire and the actual data collection were obtained.

2.4. Study Tool and Data Collection. The study tool for this study was a semistructured questionnaire that was piloted from $29^{\text {th }}$ April to $6^{\text {th }}$ May 2020. The outcome of the piloting aided in the removal of ambiguous questions and restructuring where necessary. The researchers undertook an analysis of all the questions to ensure the face validity of the study tool. This semistructured questionnaire was divided into sections that aimed at collecting data on respondents' sociodemographic characteristics as well as their level of awareness of Green care. The link to the questionnaire in the Google Forms, https://forms.gle/NZFE1rgHnRk44bKi8 was sent to the WhatsApp accounts of the randomly selected students between $6^{\text {th }}$ July and $7^{\text {th }}$ August 2020 for those who consented to be part of the study, to complete the form and then submit. If a respondent was unavailable, the next respondent in the list was contacted. Reminder messages were sent to the respondents to encourage them to complete the forms after which they were to alert the researchers of their successful submission of the form.

2.5. Statistical Analysis. Data collected in Microsoft Excel were cleaned of duplicates and then analyzed using IBM Statistical Package for Social Sciences (SPSS) version 25.0. 
The results were presented into frequencies and percentages, as well as a chart. The association between the sociodemographic characteristics and respondents' awareness of Green care was measured using Chi-square. The relationship between variables was considered as statistically significant only if $p$ value $<0.05$ at a confidence interval of $95 \%$.

\section{Results}

3.1. Sociodemographic Characteristics of Respondents. The majority of respondents were males, 136 (66.0\%), were Christians, 153 (74.3\%), and had fathers who had attained tertiary-level education, 140 (68.0\%). Most respondents were between the ages of 25 and 29 years, 97 (47.1\%), grew up in the cities, $102(49.5 \%)$, were $4^{\text {th }}$-year medical students, 95 (46.1\%), belonged to high-income families, 101 (49.0\%), and had mothers who had tertiary-level education, 78 (37.9\%). Table 1 shows the sociodemographic characteristics of the respondents.

3.2. Awareness Level of Green Care among Respondents. Only a paltry, 7 (3.4\%), of the respondents had ever heard of Green care with a lesser number, 5 (2.4\%), indicating they knew what Green care is. Even of those who indicated knowing what Green care was, only $3(60 \%)$ were able to correctly define what it was. Again, the majority, 170 (82.5\%), had never heard of Animal-Assisted Therapy (AAT) or Animal-Assisted Intervention (AAI). For those who had ever heard of AAT, movies, 10 (27.8\%), and television, 10 (27.8\%), were their first-ever sources of information on this alternative therapy. Throughout the educational lives of these respondents, only $1(0.5 \%)$ had ever been exposed to AAT during academic activities. Table 2 shows the level of awareness of respondents on Green care as an alternative therapy. Although most respondents, 63 (30.6\%) were not sure if they would welcome the introduction of AAT as a course of study during their university education, cumulative majority, 122 (59.3\%), exhibited various levels of interest in registering for such a course whenever it becomes part of their academic curriculum.

3.3. How Respondents Wish to Be Educated on AnimalAssisted Therapy. A combination of lectures and the practical sessions was the most preferred method of course delivery by the majority, 146 (70.9\%), of respondents who wish to acquire knowledge and skills on Animal-Assisted Therapy and it should be introduced as part of their academic activity. The least-preferred method was tutorials only, $1(0.5 \%)$. Figure 1 shows methods by which respondents would wish to be educated on Animal-Assisted Therapy.

3.4. Relationship between Sociodemographic Characteristics of Respondents and Their Awareness of Animal-Assisted Therapy. The relationship between the sociodemographic characteristics and the level of awareness of respondents about AAT is as shown in Table 3. Respondents older than 29 years were most aware of AAT (23.5\% vs. $12.4 \%-20.7 \%)$ just as persons ascribing to other religions besides Islam and Christianity $(66.7 \%$ vs. $15.7 \%-18.0 \%)$, but there were no significant differences between the various categories of these variables. Attaining higher educational qualifications by parents, especially the mothers, increases the level of awareness of respondents, although no significant relationship was found $(24.4 \%$ vs. $7.1 \%-18.6 \% ; p>0.05)$. The $4^{\text {th }}$-year clinical-level medical students exhibited the highest level of awareness of AAT compared to their seniors in the $5^{\text {th }}$ and $6^{\text {th }}$ year, but there was no significant association in their awareness levels (21.1\% vs. $13.5 \%-13.6 \%)$. Female respondents showed better awareness of AAT than their male counterparts, and the difference was found to be statistically significant $(28.6 \%$ vs. $11.0 \%$; $p=0.003)$. Respondents from middle-income families showed the greatest awareness level compared to those from the low- and highincome homes, but the difference was not statistically significant $(24.7 \%$ vs. $10.7-12.9 \%)$.

\section{Discussion}

The use of Green care for the promotion of health and management of various human physiological disorders is reported to be in great use in Europe, North America, and some Nordic countries [4, 12, 23]. Green care had proven useful in the management of psychiatric clients, vulnerable children, persons with learning disabilities, and drug addicts, as well as persons experiencing burnouts $[1,2]$. In countries where Green care service is widely used, several professionals such as a physical and occupational therapist, social workers, teachers, and others of various specialties form an integral part of this treatment method [4]. These professionals could have clients referred to them by medical doctors who appreciate the relevance of this alternative therapy to the restoration of good health. This study found as low as $3.4 \%$ ever hearing of Green care in general, although a higher number of $17.5 \%$ had heard of AAT. If almost half $(53.8 \%)$ of the respondents were in their $5^{\text {th }}$ or $6^{\text {th }}$ year of medical training possess such a low level of awareness about Green care and AAT, it provides an inkling of the present and the immediate future state of Green care in a developing country such as Ghana that is endowed with a great diversity of flora and fauna. Nevertheless, almost 6 out of 10 respondents (59.3\%) willing to acquire knowledge on AAT during their medical training through lectures and practical sessions bodes well for the future of Green care in Ghana if it is included in the curriculum of health-training institutions. The zeal to acquire knowledge and skills on AAT among the respondents in this study was greater than the $48 \%$ reported among graduate Clinical Psychology students in Canada where there is a growing practice of Green care [29]. These Canadian students, just like the respondents in this study, also had almost no exposure to AAT during their time in school. This suggests that even in some developed countries, Green care is yet to be incorporated into their health systems. This study did not find any statistically significant association with several of the 
TABLE 1: Sociodemographic characteristics of respondents.

\begin{tabular}{|c|c|c|c|}
\hline Variable & Subgroup & Frequency & Percentage \\
\hline \multirow{2}{*}{ Sex } & Female & 70 & 34.0 \\
\hline & Male & 136 & 66.0 \\
\hline \multirow{3}{*}{ Age } & $20-24$ & 92 & 44.7 \\
\hline & $25-29$ & 97 & 47.1 \\
\hline & $>29$ & 17 & 8.3 \\
\hline \multirow{3}{*}{ Religion } & Christianity & 153 & 74.3 \\
\hline & Islam & 50 & 24.3 \\
\hline & Others & 3 & 1.5 \\
\hline \multirow{5}{*}{ Where you grew up? } & Village & 16 & 7.8 \\
\hline & District capital & 30 & 14.6 \\
\hline & Town & 34 & 16.5 \\
\hline & Regional capital & 24 & 11.7 \\
\hline & Cities & 102 & 49.5 \\
\hline \multirow{3}{*}{ Level of study } & Level 400 ( $4^{\text {th }}$ year $)$ & 95 & 46.1 \\
\hline & Level 500 ( $5^{\text {th }}$ year $)$ & 52 & 25.2 \\
\hline & Level 600 ( $6^{\text {th }}$ year $)$ & 59 & 28.6 \\
\hline \multirow{4}{*}{ Father's highest educational level } & No formal education & 20 & 9.7 \\
\hline & Basic education & 22 & 10.7 \\
\hline & Senior-high-school education & 24 & 11.7 \\
\hline & Tertiary education & 140 & 68.0 \\
\hline \multirow{4}{*}{ Mother's highest educational level } & No formal education & 42 & 20.4 \\
\hline & Basic level education & 43 & 20.9 \\
\hline & Senior-high-school education & 43 & 20.9 \\
\hline & Tertiary-level education & 78 & 37.9 \\
\hline \multirow{3}{*}{ Family's income level } & Low income & 28 & 13.6 \\
\hline & Middle income & 77 & 37.4 \\
\hline & High income & 101 & 49.0 \\
\hline
\end{tabular}

TABLE 2: Level of awareness of Green care among respondents.

\begin{tabular}{|c|c|c|c|}
\hline Variable & Subgroup & Frequency & Percentage \\
\hline \multirow{2}{*}{ Have you heard of Green care before $(n=206)$} & Yes & 7 & 3.4 \\
\hline & No & 199 & 96.6 \\
\hline \multirow{2}{*}{ Do you know what is Green care? $(n=206)$} & Yes & 5 & 2.4 \\
\hline & No & 201 & 97.6 \\
\hline \multirow{2}{*}{ Definition of Green care $(n=5)$} & Correct & 3 & 60.0 \\
\hline & Incorrect & 2 & 40.0 \\
\hline \multirow{2}{*}{ Ever heard of animal-assisted therapy (AAT) or animal-assisted intervention (AAI) } & Yes & 36 & 17.5 \\
\hline & No & 170 & 82.5 \\
\hline \multirow{6}{*}{ Earliest source of information on AAT $(n=36)$} & Book & 2 & 5.6 \\
\hline & Friend & 3 & 8.3 \\
\hline & Internet & 7 & 19.4 \\
\hline & Movies & 10 & 27.8 \\
\hline & School & 4 & 11.1 \\
\hline & Television & 10 & 27.8 \\
\hline \multirow{2}{*}{ Have you, at any point in your education, been exposed to AAT? } & Yes & 1 & 0.5 \\
\hline & No & 205 & 99.5 \\
\hline \multirow{7}{*}{ I will be happy if AAT is introduced as a course that I can register and study at this university } & Strongly disagree & 11 & 5.3 \\
\hline & $\begin{array}{c}\text { Moderately } \\
\text { disagree }\end{array}$ & 5 & 2.4 \\
\hline & Slightly disagree & 5 & 2.4 \\
\hline & Not sure & 63 & 30.6 \\
\hline & Slightly agree & 49 & 23.8 \\
\hline & Moderately agree & 37 & 18.0 \\
\hline & Strongly agree & 36 & 17.5 \\
\hline
\end{tabular}




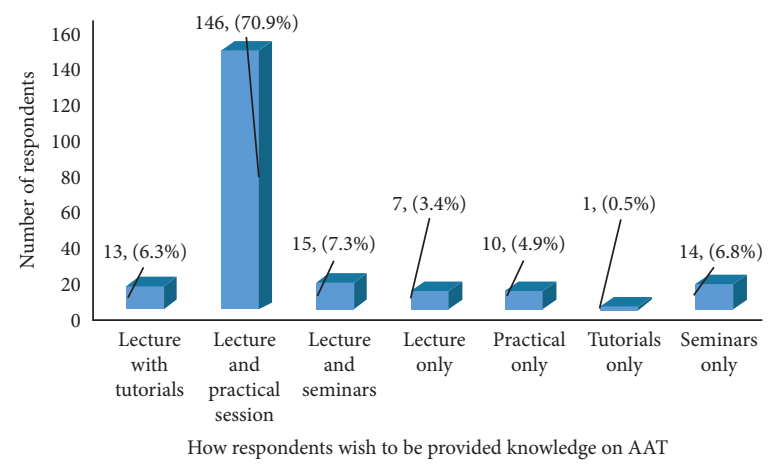

Figure 1: How respondents wish to be educated on AAT.

TABLE 3: Relationship between sociodemographic characteristics of respondents and their awareness of animal-assisted therapy.

\begin{tabular}{|c|c|c|c|c|}
\hline \multirow{2}{*}{ Variable } & \multirow{2}{*}{ Subgroup } & \multicolumn{2}{|c|}{ Ever heard of AAT? } & \multirow{2}{*}{$p$ value } \\
\hline & & No & Yes & \\
\hline \multirow{3}{*}{ Age } & $20-24$ & $73(79.3 \%)$ & $19(20.7 \%)$ & \multirow{3}{*}{0.240} \\
\hline & $25-29$ & $85(87.6 \%)$ & $12(12.4 \%)$ & \\
\hline & $>29$ & $13(76.5 \%)$ & $4(23.5 \%)$ & \\
\hline \multirow{2}{*}{ Sex } & Male & $121(89.0 \%)$ & $15(11.0 \%)$ & \multirow{2}{*}{$0.003^{*}$} \\
\hline & Female & $50(71.4 \%)$ & $20(28.6 \%)$ & \\
\hline \multirow{3}{*}{ Religious affiliation } & Christianity & $129(84.3 \%)$ & $19(15.7 \%)$ & \multirow{3}{*}{0.065} \\
\hline & Islam & $41(82.0 \%)$ & $9(18.0 \%)$ & \\
\hline & Others & $1(33.3 \%$ & $2(66.7 \%)$ & \\
\hline \multirow{5}{*}{ Where respondents grew up } & Village & $16(100.0 \%)$ & $0(0.0 \%)$ & \multirow{5}{*}{0.147} \\
\hline & District capital & $26(86.7 \%)$ & $4(13.3 \%)$ & \\
\hline & Town & $26(76.5 \%)$ & $8(23.5 \%)$ & \\
\hline & Regional capital & $22(91.7 \%)$ & $2(8.3 \%)$ & \\
\hline & City & $81(79.4 \%)$ & $21(20.6 \%)$ & \\
\hline \multirow{3}{*}{ Level of study } & Level 400 ( $4^{\text {th }}$ year $)$ & $75(78.9 \%)$ & $20(21.1 \%)$ & \multirow{3}{*}{0.356} \\
\hline & Level 500 ( $5^{\text {th }}$ year $)$ & $45(86.5 \%)$ & $7(13.5 \%)$ & \\
\hline & Level 600 ( $6^{\text {th }}$ year $)$ & $51(86.4 \%)$ & $8(13.6 \%)$ & \\
\hline \multirow{4}{*}{ Father's highest educational level } & No formal & $18(90.0 \%)$ & $2(10.0 \%)$ & \multirow{4}{*}{0.242} \\
\hline & Basic & $20(90.9 \%)$ & $2(9.1 \%)$ & \\
\hline & Senior high & $17(70.8 \%)$ & $7(29.2 \%)$ & \\
\hline & Tertiary & $116(82.9 \%)$ & $24(17.1 \%)$ & \\
\hline \multirow{4}{*}{ Mother's highest educational level } & No formal & $39(92.9 \%)$ & $3(7.1 \%)$ & \multirow{4}{*}{0.077} \\
\hline & Basic & $38(88.4 \%)$ & $5(11.6 \%)$ & \\
\hline & Senior high & $35(81.4 \%)$ & $8(18.6 \%)$ & \\
\hline & Tertiary & $59(75.6 \%)$ & $19(24.4 \%)$ & \\
\hline \multirow{3}{*}{ Family income level } & Low & $25(89.3 \%)$ & $3(10.7 \%)$ & \multirow{3}{*}{0.073} \\
\hline & Middle & $58(75.3 \%)$ & $19(24.7 \%)$ & \\
\hline & High & $88(87.1 \%)$ & $13(12.9 \%)$ & \\
\hline
\end{tabular}

${ }^{*}$ Statistically significant.

sociodemographic characteristics of the respondents such as age and religious affiliation. One would have thought that having parents with a high educational qualification will have some significant relationship with the respondent's awareness level of AAT because income levels are expected to rise with higher educational qualifications making it possible for such families to afford to keep animals. This was not the case in this study. The sex of the respondents was, however, found to be significantly associated with their awareness about AAT. Phillips et al. found in a survey among 1,902 female and 1,530 male students from 102 universities in 11 Eurasian countries that females had greater concern for animal welfare and rights than males and also were more likely to keep pets, hence possessing high awareness level on the use of animals for therapy [30]. Herzog also reported that females commonly have more positive behaviours and attitudes towards animals than their male counterparts [31]. This, therefore, explains why this study found female medical students being significantly more aware of AAT than their male colleagues. This study, however, brings to the fore the need for more studies in other developing countries and among healthcare professionals. Considering how valuable Green care practices have been in restoring the health of patients in developed 
countries [13-15, 32], health-related institutions, especially medical schools, in developing countries must expose their students to the various forms of Green care so that they can recommend this well-proven treatment modality to those whose conventional medicines seem unable to resolve their health challenges. Although using simple randomization limited biases, the results of this study may not represent the true knowledge on Green care among all medical students in Ghana since the study was carried out in only one out of the five public medical schools in Ghana. This study seems to be the first ever in Ghana and especially among medical students, and conducting similar studies across all other medical schools in Ghana in the future would provide a better assessment of medical students knowledge of and attitude towards this alternative healthcare system. To ascertain the true state of knowledge on Green care among practicing doctors, there may be a need for a similar study to be conducted amongst them. Similar studies can also be conducted among all other categories of practicing health professionals.

\section{Conclusions}

Awareness of Green care practices among medical students in Ghana was highly inadequate, but the desire of the majority of them to acquire knowledge and skills in this proven alternative therapy makes its future use in Ghana promising. Including Green care in the academic curriculum of medical schools could enhance its use. This will go a long way to offer patients in Ghana an alternative healthcare system.

\section{Data Availability}

The results presented are adequate to support the conclusion of this study. However, the lead author is available to provide extra data upon request.

\section{Ethical Approval}

The Ethics Committee of the School of Medicine and Health Sciences of the University for Development Studies provided prior approval for this study with a certificate number of SMSAHS/JIRC/0005.

\section{Consent}

Data were collected from participants only after they gave their informed consent to take part in the study.

\section{Conflicts of Interest}

The authors declare that there are no conflicts of interest regarding the publication of this article.

\section{Authors' Contributions}

Evans Paul Kwame Ameade and Benjamin Yeboah Ofori conceived the idea and designed the questionnaire. Evans Paul Kwame Ameade collected and analyzed the data. Evans
Paul Kwame Ameade, Linda Ama Owusuaa Amoah, and Benjamin Yeboah Ofori drafted the manuscript.

\section{References}

[1] J. Sempik, R. Hine, and D. Wilcox, Eds., Green Care: A Conceptual Framework: A Report of the Working Group on Health Benefits of Green Care, Loughborough University, Loughborough, UK, 2010.

[2] B. B. Bock and S. J. Oosting, "A classification of green care arrangements in Europe," in The Economics of Green Care in Agriculture, pp. 15-26, Loughborough University, Loughborough, UK, 2010.

[3] R. E. Salomon, A. D. Salomon, and L. S. Beeber, "Green care as psychosocial intervention for depressive symptoms: what might be the key ingredients?" Journal of the American Psychiatric Nurses Association, vol. 24, no. 3, pp. 199-208, 2018.

[4] D. K. Haubenhofer, M. Elings, J. Hassink, and R. E. Hine, "The development of green care in western European countries," Explore, vol. 6, no. 2, pp. 106-111, 2010.

[5] J. A. Jungmair and O. Meixner, "Green care day care for the elderly on austrian farms," Economia Agro-Alimentare, vol. 19, pp. 151-168, 2017.

[6] J. Sempik, C. Rickhuss, and A. Beeston, "The effects of social and therapeutic horticulture on aspects of social behaviour," British Journal of Occupational Therapy, vol. 77, no. 6, pp. 313-319, 2014.

[7] J. Hassink and M. Van Dijk, Eds., Farming for Health: Greencare farming across Europe and the United States of America, Springer Science \& Business Media, Vol. 13, Berlin, Germany, 2006.

[8] C. Chalquist, "A look at the ecotherapy research evidence," Ecopsychology, vol. 1, no. 2, pp. 64-74, 2009.

[9] J. Hassink, W. Hulsink, and J. Grin, "Farming with care: the evolution of care farming in The Netherlands," NJAS Wageningen Journal of Life Sciences, vol. 68, pp. 1-11, 2014.

[10] M. Jordan and J. Hinds, Ecotherapy: Theory, Research, and Practice, Macmillan International Higher Education, Stuttgart, Germany, 2016.

[11] J. Sempik and T. Spurgeon, "Lessons learnt- evidence from practice: the use of plants and horticulture in promoting health and well-being," in Proceedings of the 6th International Congress on Education in Botanic Gardens, Richmond, Surrey, United Kingdom: Botanic Gardens Conservation International in Association with Oxford: University of Oxford Botanic Garden, Oxford, UK, September 2006.

[12] R. Hine, J. Peacock, and J. N. Pretty, Care Farming in the UK: Evidence and Opportunities, University of Essex, Colchester, Essex, Available at http://sanctuaryone.org/wp-content/ uploads/2015/01/care_farm_research_paper_2.pdf. Retrieved, 17th September 2020, 2008.

[13] G. B. Diette, N. Lechtzin, E. Haponik, A. Devrotes, and H. R. Rubin, "Distraction therapy with nature sights and sounds reduces pain during flexible bronchoscopya," Chest, vol. 123, no. 3, pp. 941-948, 2003.

[14] T. Hartig, G. W. Evans, L. D. Jamner, D. S. Davis, and T. Gärling, "Tracking restoration in natural and urban field settings," Journal of Environmental Psychology, vol. 23, no. 2, pp. 109-123, 2003.

[15] R. S. Ulrich, R. F. Simons, and M. A. Miles, "Effects of environmental simulations and television on blood donor stress," Journal of Architectural and Planning Research, vol. 20, no. 1, pp. 38-47, 2003. 
[16] W. Bird, Natural Thinking: Investigating the Links between the Natural Environment, Biodiversity and Mental Health [online], The Royal Society for the Protection of Birds, Sandy, UK, 2007.

[17] D. Silkwood-Sherer and H. Warmbier, "Effects of hippotherapy on postural stability, in persons with multiple sclerosis: a pilot study," Journal of Neurologic Physical Therapy, vol. 31, no. 2, pp. 77-84, 2007.

[18] B. Berget, O. Ekeberg, and B. O. Braastad, "Attitudes to animal-assisted therapy with farm animals among health staff and farmers," Journal of Psychiatric and Mental Health Nursing, vol. 15, no. 7, pp. 576-581, 2008.

[19] M. Elings and J. Hassink, "Green care farms, a safe community between illness or addiction and the wider society," Therapeutic Communities, vol. 29, no. 3, pp. 310-322, 2008.

[20] S. De Bruin, S. Oosting, A. van der Zijpp, M.-J. Enders-Slegers, and J. Schols, "The concept of green care farms for older people with dementia," Dementia, vol. 9, no. 1, pp. 79-128, 2010.

[21] I. Pedersen, E. W. Martinsen, B. Berget, and B. O. Braastad, "Farm animal-assisted intervention for people with clinical depression: a randomized controlled trial," Anthrozoös, vol. 25, no. 2, pp. 149-160, 2012.

[22] B. Nosbusch, Benefits of Green Care for Youth with a Mental Health Diagnosis, Retrieved from Sophia, the St. Catherine University repository website: https://sophia.stkate.edu/msw_ papers/645, 2016.

[23] A. M. Steigen, R. Kogstad, and J. K. Hummelvoll, “Green Care services in the Nordic countries: an integrative literature review," European Journal of Social Work, vol. 19, no. 5, pp. 692-715, 2016.

[24] B. Artz and D. Bitler Davis, "Green care: a review of the benefits and potential of animal-assisted care farming globally and in rural America," Animals, vol. 7, no. 4, p. 31, 2017.

[25] N. I. Platnick, "Patterns of biodiversity: tropical vs temperate," Journal of Natural History, vol. 25, no. 5, pp. 1083-1088, 1991.

[26] W. F. Laurance, "Have we overstated the tropical biodiversity crisis?" Trends in Ecology \& Evolution, vol. 22, no. 2, pp. 65-70, 2007.

[27] Ghana Statistical Service, Population and Housing Census. Summary of Final Results, https://statsghana.gov.gh/gssmain/ fileUpload/pressrelease/2010_PHC_National_Analytical_ Report.pdf, 2010.

[28] W. G. Cochran, Sampling Techniques, John Wiley \& Sons, New York, NY, USA, 3rd edition, 1977.

[29] N. Lutzky-Cohen, "Motivation to use animal assisted therapy among psychotherapy and counselling graduate students (master dissertation)," Ontario Institute for Studies in Education, University of Toronto, Available at https://tspace. library.utoronto.ca/bitstream/1807/71682/3/Lutzky-Cohen_ Noga_201603_MA_thesis.pdf. Retrieved on 17th September, 2020, 2016.

[30] C. Phillips, S. Izmirli, J. Aldavood, M. Alonso, B. I. Choe et al., "An international comparison of female and male students' attitudes to the use of animals," Animals, vol. 1, no. 1, pp. 7-26, 2011.

[31] H. A. Herzog, "Gender differences in human-animal interactions: a review," Anthrozoös, vol. 20, no. 1, pp. 7-21, 2007.

[32] L. Keniger, K. Gaston, K. Irvine, and R. Fuller, "What are the benefits of interacting with nature?" International Journal of Environmental Research and Public Health, vol. 10, no. 3, pp. 913-935, 2013. 